\title{
An Examination of the Elements of Transportation, Enslavement and Exploitation in Trafficking in Human Beings under International and Nigeria Anti-Trafficking Laws
}

\author{
Emily Alemika, Ibe Okegbe Ifeakandu* \\ Department of Public Law, Nigerian Institute of Advanced Legal Studies, Supreme Court Complex, Abuja, Nigeria \\ Email: ‘ibybenji@gmail.com, *ibybenji@ibybenji@outlook.com
}

How to cite this paper: Alemika, E., \& Ifeakandu, I. O. (2019). An Examination of the Elements of Transportation, Enslavement and Exploitation in Trafficking in Human Beings under International and Nigeria Anti-Trafficking Laws. Beijing Law Review, 10, 1116-1135

https://doi.org/10.4236/blr.2019.104060

Received: August 18, 2019

Accepted: September 27, 2019

Published: September 30, 2019

Copyright (c) 2019 by author(s) and Scientific Research Publishing Inc. This work is licensed under the Creative Commons Attribution International License (CC BY 4.0).

http://creativecommons.org/licenses/by/4.0/

\begin{abstract}
Trafficking in Human Beings (THB) is a heinous crime that is committed against human (person) with intent to exploit. There are several constituent elements that are integral parts that make the act of trafficking a crime. These include, among others, the inhuman nature of transportation, the enslavement and the exploitation associated with the practices. This paper examines the specific elements of transportation, enslavement and exploitation in THB. Choice of these elements for discourse is occasioned by the crucial roles they play in the crime of THB, and the fact that they combine with other elements to provide the physical and mental elements that make the conduct a crime under international and Nigeria municipal laws. For a critical analysis of these three key elements, several and relevant materials were consulted, including the two main national statutes on TBH (Violence Against Persons (Prohibition) Act. (2015) and Trafficking in Persons (Prohibition) Enforcement and Administration Act (TIPPEAA) 2015), and the UN Convention, protocols and policies against human trafficking. From the critical examination and the analysis, it was established that the three key elements still remain critical to the sustainability of THB in Nigeria and globally. Therefore, suggestions and recommendations are proffered to focus on dismantling these strongholds to reduce the prevalence of Trafficking in human beings at all levels.
\end{abstract}

\section{Keywords}

Enslavement, Transportation, Exploitation, Human Trafficking, Anti-Trafficking 


\section{Introduction}

Trafficking in human beings (THB) is a brazen affront to humanity. It disempowers victims and places significant strain on state resources when a) seeking, adopting and implementing countermeasures; and b) providing assistance to victims as observed by Abdulraheem \& Oladipo (2010) and Cockell (2000). Despite its pervasiveness, it goes largely unnoticed, especially in the case of children because of the surreptitiousness with which it is practiced. It is a criminal act which may be orchestrated by individuals, criminal organised or loosely organised groups, which may also be involved in smuggling of weapons and trafficking of drugs (narcotics) (Denton, 2010; UNODC, 2013; Srikantia, 2007). It can be perpetrated internally or across border; and is recognised as a huge phenomenon. In September 2017, the ILO estimated that 24.9 million men, women and children were victims of human trafficking around the globe (ILO, 2017). According to the United Nations (UN), 51\% of trafficking victims are women and $20 \%$ girls; meaning $71 \%$ of THB victims are women and girls (UNODC, 2018).

Other characteristics associated with THB include its universality as it affects almost every country of the world; and its attractiveness to criminals due to high profitability raking millions of untaxed dollars annually for the traffickers (UNODC, 2018); and minimum risks in perpetrating it. The Equality Now fact sheet estimates that the sex trafficking industry alone pulls in an estimated $\$ 99$ billion each year (Equality Now, 2019). When this figure is added to the amount of money traffickers which make from other forms of trafficking, such as forced labour and organ harvesting, etc., the total could run into trillions of dollars per annum. THB is also multidimensional as it is a criminal justice, migration, labour, or health etc., meaning it can be examined from any perspective.

The process of trafficking which involves the movement or transportation of persons from one place to another whether internally or externally is not only barbaric and dehumanising, it also violates the dignity and integrity of the human person and against international standard best human rights practices; as well as the criminal justice system of any given country. Enslaving or subjecting victims to slavery or a slavery-like and other exploitative situations violates the dignity of the victim and constitutes an affront to the justice system that criminalizes THB which also seeks protection for the citizenry. Its impacts on victims and the society at large make it imperative to adopt enhanced measures to combat the act of human trafficking, including effective law enforcement. While efforts have been made across the globe to confront the problem headlong, the international community emphasises the need to localise efforts for effectiveness. Accordingly, Nigeria has adopted several measures ranging from legal and institutional framework, to policy, administrative and other measures to counter the menaces. However, these efforts remain seemingly infinitesimal compared to the volume of trafficking that takes place in the country yearly; due to several identifiable factors, such as poverty, illiteracy, socio-cultural accep- 
tance and globalisation, amongst others.

In the context of this paper however, THB is examined from the perspective of criminal justice, particularly the criminal elements of transportation, enslavement and exploitation under international and Nigeria anti-THB laws. Although THB is an activity that contains several criminal elements, these three are chosen for discussion due to their centrality and the crucial role they play in facilitating and defining THB; and the fact that they can combine with other elements to provide the basis for recognising THB as crime. For purposes of clarity, the paper is divided into six parts. Part one is the introduction. Historical update, theoretical foundation and clarification of terms/concepts is undertaken in part two while the constituent elements of transportation, enslavement and exploitation are discussed in part three. Part four discusses the impacts of human trafficking, with specific reference to the elements under review. Recommendations are made in part five while part seven concludes the paper.

\section{Historical and Update of Trafficking in Human Beings}

Although the concept of THB is relatively new, it has links with slave trade and slavery practices (Friesendorf, 2007); and has been traced to an era during which savagery, exploitation and mischief wereee prevalent (Mills, 2001). For Diamond, it precedes our modern society (Diamond, 1987). Historical antecedents of the periods, characterised by practices of taking women and children as spoils of war; and bonded slavery with the shipment of Africans to America and Europe (Unser, 1979), attracted public condemnation leading to the adoption of some initiatives. The initiatives include, but are not limited to (a) adoption of the 1926 Slavery Convention (25 December 1976), which gave a vague definition of the concept of slavery (article 1 Slavery Convention); (b) Supplementary Slavery Convention (Social Council Resolution 608 (XXI), 30 April 1956) which clearly defined slavery and slavery-like practices (article 7 (a) (b)); and (c) condemnation of bonded labour at the international level. According to United States Department of state (USDOS), the result was the enactment of domestic antislavery laws by many countries, including Nigeria, to prohibit slavery practices (USDOS, 2010).

The similarities, which THB bears with prevalent slavery practices, attracted overwhelming public concern, which began several years ago, especially as it relates to commercial exploitation of women and young girls forced into prostitution at the end of the nineteenth century (Kempadoo, 2007). Accordingly, the international community engaged several activities such as conferences and high-powered meetings leading to the adoption of several international legal instruments and national law provisions (Trafficking in Persons (Prohibition) Enforcement and Administration Act (TIPPEAA), which was enacted in 2003, and amended in 2005, Child Rights Act (CRA), 2003; Constitution of the Federal Republic of Nigeria (CFRN), 1999; Violence Against Persons Prohibition Act (VAPPA), 2015), all of which seeks to prohibit and punish slavery and sla- 
very-like practices in all its ramifications. The seemingly limited scope of the earlier instruments, one of which is the narrow definition of trafficking, led to the adoption of the TIPP. TIPP later adopted a definition of THB that is more comprehensive and widely accepted, taking into consideration the critical elements of the crime, such as those under review. The definition reflects a compromise, adopting language that gives much room for states to address the issue of prostitution and others however they like. The TIPP also accords states the opportunity to widen the dragnet of conducts that constitutes THB, and to enact laws that prohibit and punish these conducts individually and independently once criminal intent can be identified. It means if transportation occurs with intent to traffic, the person can be charged, tried and punished for the offence of THB.

\section{Theoretical Foundation and Conceptual Clarification of Trafficking in Human Beings}

THB constitutes a crime in international legal instruments and Nigerian criminal law; and has been so qualified and dealt with accordingly under various criminal provisions (ss. 13, 82, TIPPEAA, 2015; ss. 369, 371 CC; ss. 21-281 PC; and s. 46, VAPPA, 2015). Regarding THB as crime and treating it as such means it possesses the requisite characteristics that qualify a conduct as crime in law

At the level of international law, the TIPP: a) provided important perspective on the crime of THB leading to better and deeper understanding of the different aspects of the conduct, including its criminal aspect, b) differentiated it from illegal activities of similar nature such as people smuggling (Naim \& Myers, 2005), c) enables THB to be internationally accepted as crime; and d) represents a turning point in anti-THB efforts at national levels (Gallagher \& Holmes, 2008; Truong, 2008). The TIPP did this by providing, in addition to a generally accepted definition, an important platform for states to adopt necessary measures to criminalise all acts constituting THB, by enacting specific national anti-THB laws (Scarpa, 2008; Allain, 2008; IOM, 2018). Following the adoption of the TIPP, several states, including Nigeria adopted several anti-THB measures, including the enactment of specific anti-THB laws. Nigeria effort in that regard is particularly significant in that the Trafficking in Persons (Prohibition) Law Enforcement and Administration Act (TIPLEAA), which was enacted in 2003, and amended in 2005 enhanced existing legal provisions such as the PC and CC dealing with THB in all its ramifications; and address some anomalies such as providing uniform justice in relation to THB for the whole country. Hence, the TIPP defines THB thus:

Trafficking in persons 'shall mean the recruitment, transportation, transfer, harbouring or receipt of persons, by means of threat or use of force or other forms of coercion, of abduction, of fraud, of deception, of the abuse of power or of a position of vulnerability or of the giving of or receiving of payments or benefits to achieve the consent of a person having control over another person, 
for the purpose of exploitation. Exploitation shall include, at the minimum, exploitation, the exploitation of the prostitution of others or other forms of sexual exploitation forced labour or services, slavery or practices similar to slavery, servitude or removal of organs.

This definition is replicated in Nigeria under the TIPPEAA (s. 82) and the VAPPA (s. 46). The definition of THB under the TIPP, TIPPEAA and VAPPA shows several implications of the crime and provides impetus for regarding a wide range of conducts, such as transportation, enslavement, and exploitation, as criminal; and the extent of liability of persons. For example, under TIPP, a trafficker can be convicted on the basis of transportation alone or any of the acts listed in article 3 even if exploitation has not yet taken place (Bales \& Soodalter, 2009). This paper shall further analyse the three basic constituent elements vis; the transportation, enslavement and exploitation as constituting integral parts of THB as a criminal offence.

\section{Constituent Elements of Trafficking in Human Beings}

In criminal law there are two basic elements usually considered in order to establish whether a crime has been committed or not. They are constituted in the legal maxim usually referred to as, actus-reus and mens-rea.

Actus reus this means, for an act to constitute crime, must be backed by action. The second maxim is the "mens-rea", meaning a criminal act must be backed up by intent.

It is the combination of both the two elements that account for a crime. In legal maxim, they are referred to as mental and physical elements. Thus for transportation, enslavement and exploitation to be established as constituent elements of THB, transportation (which an act) of victims must have taken place with intention to engage in the trafficking those victims. There also must be some form of confinement or harbouring of victim for the purpose of trafficking. Below are some detailed explanations backed up with some decided cases to establish the relationships between those elements and the THB.

\subsection{Transportation}

THB as defined under the TIPP (art. 3), TIPPEAA (s. 82) and the VAPPA (s. 46) amongst others, has been summarized as conduct having three aspects-the act-what is done, means-how it is done and purpose-why it is done (UNODC, 2019), all of which have been criminalized (s. 13 (2) (3) of TIPPEA). Under s. 13 (6) of TIPPEAA, transportation is regarded as one of the element of THB once the main ingredients of the elements of crime- "mens-rea and actus reus" can be established. Thus, once transportation or recruitment, or harbouring etc., is present, THB is deemed to have been committed irrespective of whether any of the means set out in the definition of THB is involved. Importantly, this section is to be construed very strictly in the case of children. For better understanding and purposes of clarification, some relevant terms such as, crime and its ele- 
ments are defined, and other concepts described or discoursed to buttress the offence of THB and its three constituent elements under examination.

Elements of Crime: The Actus Reus and Mens Rea and THB

Criminal law requires that for a conduct to constitute crime, two essential elements must be present, i.e. the act "guilty act" known as actus reus, and criminal intent-"guilty mind" known as mens rea. In the case of Babalola \& Ors v State (1989), the Nigerian Supreme Court (SC) ruled that it is a settled principle of law that no man can be convicted of crime unless "his physical conduct, (the actus reus) is accompanied with a guilty mental element-a mind at fault, a mens rea".

a) Actus Reus:

Generally, the requisite actus reus must be proved to exist at all times for a crime to be established. In particular, where the actus reus includes the specific consequences of conduct, prosecution must prove that those consequences have been caused by the accused. However, proving actus reus may not be as clear cut as it seems, especially where there is a chain of causation, i.e. where consequences are not solely caused by the conduct of the accused. In that regard, although the perpetrator could still be held liable for all consequences whether or not they are caused solely by his conduct, as held in the English case of R $V$ Warburton [2006], Hence, the act of transportation per se may not constitute crime but once such transportation of human beings is linked with the intention to recruit or harbour the victim for the purpose of trafficking such act constitute THB.

\section{b) Mens Rea}

A fundamental principle of criminal law is to the effect that a crime consists of both mental and physical elements. The mens rea of a crime is the mental element, known as criminal intent; and it connotes a person's awareness that his or her conduct is criminal. It is usually defined as guilty mind or guilty knowledge (Ashworth, 2006). The origin of this principle is traced to the 1600s when judges in England began to rule that conduct alone could not occasion criminal liability unless the conduct is accompanied by a guilty mind as stated by the Nigerian supreme Court in the case of Speiss v Oni (2016). Normally, the extent of mens rea required for a crime varies according to the offence. Also, the mens rea of each offence is distinct, separate and independent; and so, a person may be held criminally liable with intent to commit a crime even if intent cannot be established in another conduct. This usually happens where a person is charged with a chain of conducts, for example, theft and criminal trespass. In this situation, even if the accused person is discharged from theft, the accused could be convicted for criminal trespass if intent to trespass can be proved. This is because laws that create offences usually stipulate the mens rea requirement; which means, a law may require that a person act knowingly, purposely or recklessly (legal-dictionary. the free dictionary.com). This position was upheld in Nigeria in the SC cases of Speiss v oni (2016) and Idagu v State (2018).

Criminal intent may be general or specific. General intents decipherable from 
the conduct itself-it arises where the outcome of a crime is not the outcome intended. Specific intent is where the act done leads to the outcome intended, such as premeditated murder. In the specific context of THB, if a person being trafficked dies in the process of being transported from point $A$ to point $B$, the general intent would be the unintended death of the victim; whereas, where a trafficker sells the victim to exploiters or exploits the victim, the specific intent is the exploitation.

Transportation is one of the commonest and most fundamental aspects of THB. It is an actus reus or physical element of THB; and plays a fundamental role in both internal and transnational THB (Polaris Project, 2019). However, as indicated earlier, mere transportation does not constitute THB unless a person has been moved by whatever means across a certain distance by any mode of transportation (Olujuwon, 2009; Nwogu, 2007) with intent and ulterior intent to traffic the person.

Normally, transportation in THB is through illegal means and can involve the commission of a series of other crimes such as forgery of travel documents in the case of cross border trafficking, official corruption and violations of victims' rights (Turner \& Kelly, 2009). For example, during transportation, victims are usually isolated and controlled leading to their being confused and psychologically bruised to submissiveness (Edward, 2008). This is because transporting THB victims from their homes and families to unfamiliar environment and unfamiliar people who may likely exploit them is often too unsettling and often results in their being dependent on their captors (UN.GIFT, 2008; UNICEF, 2018).

Movement of people in THB involves the involuntary transportation of a person or a group of persons, which could be through the use of violence, fraud or any other means. Transportation would normally involve cases of physiological and psychological coercion, manipulation and exploitation (Kleimenov \& Shamkov, 2005). According to USDOS, "movement is THB as any person who is recruited, harboured, provided or obtained through force, fraud, coercion for the purpose of subjecting that person to involuntary servitude, forced labour, or commercial sex qualifies as a trafficking victim" (USDOS, 2019).

In Bassey $v$ Attorney General of the Federation (2015), the Court of Appeal held: "inducement of a person to go from any place ..." (Per Onyekachi Otisi, 5-6) contravenes ss. 12 (a) and 19(b) of the repealed 2003 Anti-Trafficking law. This ruling followed the position of the Court of appeal in Omadiareb \& Anor $v$ $A G F$ (2013), where the appellants were charged with and convicted for moving a person from Edo state to Cross River state with intent to traffic the victim to Cameroon, by a Federal High court, sitting in Calabar. Although the appeal succeeded for what the CA regarded as lack of "proof beyond reasonable doubt" (see s. 36 (12) CFRN; Ukpong $v$ State (2019), existence of the element of transportation was not in doubt. However, prosecution was unable to tie intent to traffic to the moving of the victim from Edo State to Cross River. This principally shows that unless it can be shown that a victim is transported by any of the means with intent to exploit, THB cannot be said to have been committed 
(OSCE, 2015).

The crucial nature of transportation to the process of THB makes it necessary for states to adopt measures that address this element (Fayomi, 2009). One way to control transportation of THB victims is to encourage or admonish those in transport and tourism businesses to get involved in the fight against THB. Accordingly, the Nigerian TIPPEAA, in addition to criminalising transportation for the purpose of exploitation, imposes obligation on transport owners and commercial carriers and operators of tour and travel agencies to do everything in their power to discourage transportation of trafficked persons within and out of the country (s. 35 of TIPPEAA, 2015). Failure to comply with this provision attracts a fine not exceeding N10, 000,000.00 (ten million Nigerian Naira) (s. 35 (4) TIPPEAA, 2015). Although liability for non-compliance is reasonably stringent, enforcement of this provision has been rendered ineffective. Thus far, no transport company has been held liable for THB even though several victims have been trafficked using one or more of the available transportation mode(s). Clearly, there is no evidence to show that transport companies are taking steps to prevent THB. Therefore, stakeholders involved in anti-THB efforts need to urgently seek ways of ensuring that transport companies comply with their obligations under the law; and made accountable where they fail to do so.

\subsection{Enslavement}

Enslavement is a difficult element to identify in THB, due to problems associated with defining the parameters of enslavement (Innocenti Insight, 2008) as separate from exploitation (Abdulraheem \& Oladipo, 2010; Nwogu, 2007). This is so because, as argued by writers (Fitzgibbon, 2003; Rijken, 2003), exploitation is a form of enslavement. Rijken (Rijken, 2003). It was argued that the element of continuous exploitation of trafficking victims is a form of enslavement because the right of ownership is fully exercised, and therefore akin to slavery (Kara 2009; Pennington et al., 2009). This right of ownership is a right, which exploiters illegally assume over their victims, which may be temporal or continuous (Orhant, 2001; Gould, 2006; Stoddard, 2009). The right of ownership may not however apply in trafficking cases except where the trafficker is the exploiter (ILO, 2007), since the trafficker may not necessarily be the exploiter.

Enslavement is a key issue in the criminal assessment of THB and has been addressed in several international legal instruments as well as Nigerian municipal provisions (art. 7 (1)(c) of the Statute of the International Criminal Court (Rome Statute)). Enslavement has a long history, having been traced back to the period of slave trade. It was present in slavery practices at the time; and in the contemporary THB as an exercise of power, authority and ownership of another (Allain, 2008; Allain, 2007). Enslavement enables the slave master to determine the extent to which the victims of slavery and THB can exercise their freedom (Kara, 2009) even though the slave master may not have been originally involved in the transportation of victims. It is the act of making slaves of one's captives. According to Allain, it was criminalized alongside piracy before the Nuremberg 
and Tokyo trials/judgments (Allain, 2008) even though circumstances under which conduct become an international crime and what the content of international criminal law is at the time, was still unclear. For him, the "notion of ownership appears to be the sine qua non of slavery in international law" (Allain, 2007). However, it must be noted that although THB and enslavement have linkages, they are not one and the same thing as enslavement can occur in situations outside THB such as in crimes against humanity as defined in international criminal law (art. 7, Rome Statute). Obokata (Obokata, 2003) lends credence to this assertion when he observed that despite strong links between enslavement and THB, they are distinct; and pointed out that the term slavery as embedded in the definition of THB shows that it is a manifestation of enslavement (Antislavery International, 2019).

Enslavement is a word with general application, having both literal (Collins, 2006) and legal meanings; and strongly denigrated by a mosaic of national legal provisions and international legal instruments that sought to abolish it in all its ramifications. These provisions which seemingly owe existence to the long years of advocacy and agitation by several organizations and some "colonial states, in the period between 1924 and 1926" brought about the definition of slavery as "the status or condition of a person over whom any or all of the powers attaching to the right of ownership are exercised" as contained in article 1 of the Slavery convention (Antislavery International, 1926; Allain, 2007).

The main focus of the Slavery Convention was to abolish slavery conditions through criminalisation. To achieve this, member states were enjoined to criminalise all slavery conditions in their respective jurisdictions as a matter of urgency. Without prejudice to sovereignty and domestic jurisdiction rights of states, Article 2 (1) (b) referred to states as "High Contracting Parties" and enjoined them to "progressively bring about the abolition of slavery in all its forms". Criminalisation of slavery practices by states was to be done through enactment of domestic laws on slavery that incorporates the provisions of the Convention and take into account the different kinds of slavery conditions. The Convention encouraged states to collaborate and help towards achieving slavery-free environment for all (article 4 of Slavery Convention).

Events prevalent in the years immediately following the adoption of the 1926 Slavery Convention began to show that set objective of abolishing slavery in its entire ramification was far from being achieved due largely to its shortcomings. Consequently, the Supplementary Convention on the Abolition of Slavery, Slave Trade, and Institutions and Practices Similar to Slavery was adopted in 1956. This later Convention adopted the provisions of the 1926 but made some improvements on it; and enjoined states to ensure that slavery, slave trade and institutions and practices similar to slavery are eliminated in all parts of the world; and for states to recognise freedom of movement as the birthright of everybody.

Significantly, modern day slavery practices do not differ in substance from the way it was practiced during the early $20^{\text {th }}$ century. For example, elements such as cunning, deceit, the use of drugs to subdue victims, including children; and the 
use of whip as part of the essential equipment of the power of the professional slaver were present during the $20^{\text {th }}$ century slavery. These elements remain basically the same in modern day slavery (Anti-Slavery Society, 2019). Antislavery International noted among other things that, a) all these elements exist in modern day slavery (THB) in many parts of the world, including Nigeria (Duffy, 2009), b) children from West Africa are kidnapped and sometimes purchased for as little as twenty to seventy dollars each depending on the age and sex of the child' by slavers who in turn sell them to bigger and wealthier slavers who then subject them to slavery conditions in sex dens-forced and unpaid domestic services, and forced labour in sweat shops, etc. In extreme cases, victims are usually killed for sacrifices or organ harvesting (Geis \& Brown, 2008; Scheper-Hughes, 2000); and c) victims, particularly girls are usually treated as "hierodulic slaves, combining the roles of agricultural slaves, domestic slaves, temple slaves and sex slaves" (Antislavery International, 2019).

In Nigeria, slavery in all its ramifications is prohibited under the various legal provisions. S. 34 of CFRN, 1999 (as amended), criminalises slavery, as a form of human rights abuse, including slavery and slavery-like practices such as forced labour. This provision is replicated in s. 22 of TIPPEAA, and several other provisions that criminalise forced labour or bonded labour, and slavery-like practices (see TIPPEAA s. 22 on forced labour; s. 24 on trafficking in slaves; s. 25 on slave dealing; ss. 271-281 of PC; and s. 369 of CC). Specifically, S. 369 of the CC criminalises slavery and slavery-like practices, and prescribes punishment of a term of imprisonment for fourteen years on conviction. Despite legislation however, THB in the country remain prevalent (UNESCO, 2006). The USDOS 2019 Trafficking in Persons (TIPP) Report (USDOS, 2019), the UNODC (UNODC, 2018) Global Trafficking in Persons (GTIP) Report, 2018; as well as the UN Special Rapporteur on trafficking in persons, especially women and children (UN Report, 2019) also indicate an upward trend in THB in Nigeria despite government's continuous effort to combat the crime. Similarly, the International Office for Migration (IOM) pointed out in its 2019 Migration Report on Nigeria, that since 2017, there has been steady increase in the volume of trafficking of women and children out of Nigeria; and painted a very gory picture of THB situation in the country to the effect that "every year, thousands of Nigerian women..." are lured into trafficking with fake promises of a better life outside Nigeria-in other African countries and Europe (IOM, 2019). Once they are taken out, they are held in slavery and slavery-like situations, very often being subjected to sexual exploitation (IOM, World Migration Report, 2018). This also speaks to the very public situation of slavery of Nigerians and other Africans in Libya where Libyan slave masters auctioned them as commodities as revealed the Cable Network News (CNN) in 2017 (Elbagir, et al, 2017). This led to the adoption of rescue project by the Nigerian government leading to the return of many back to Nigeria (NAPTIP, 2019; Committee on the Rights of the Child Report, 2019).

The serious nature of enslavement calls for effective law enforcement. To aid 
law enforcers, adequate understanding of what constitutes slavery and enslavement is crucial due largely to the central role this can play in anti-THB law enforcement in Nigeria; and advocacy must be enhanced, not only for purposes of educating the public about what constitute enslavement, but also law enforcers. This is because terms such as sale of children, abduction, and coercion differ in meaning according to particular contexts. In Nigeria like many parts of West Africa for example, people, especially rural people, are yet to understand why a child should a) not be abducted for any reason (especially for religious reasons where a child is believed to "possess evil spirit and need to be delivered") (Amuda, 2011); b) be sold to raise money for the purpose of solving "more important family problems" (Kuyini \& Mahama, 2014); or c) why someone else should not be enslaved by another as a mark of strength and or wealth (Manning, 1983). And even where child fostering and adoption are common practices in Africa. Depending on the particular instance, any of these will not be seen as criminal; and this is still a big problem needing attention. This does not however exculpate perpetrators since ignorance of the law is no excuse (s. 22 of CC).

\subsection{Exploitation}

The definition of THB in the context of TIPP made reference to trafficking in human beings for the purpose of exploitation but did not define exploitation. Nevertheless, the definition includes exploitative actions such as prostitution of others, and other forms of exploitative labour relationships that are non-sexual (s. 15, TIPPEAA, 2015). These include, practices similar to slavery such as indentured or bonded labour, child labour, or oppressive forms of labour. The Nigerian TIPPEAA did not employ the word exploitation in its definition but nonetheless stated "for the purpose of placing or holding the person whether for or not in involuntary servitude (domestic, sexual or reproductive) in force or bonded labour, or in slavery-like conditions" (e.g., s. 82 TIPPEAA); which can be astutely interpreted to mean exploitation. The use of the phrase "for the purpose of exploitation" lends credence to the fact that subsequent and continuous exploitation of victims by exploiters such as factory and brothel owners qualifies an act as THB, and also differentiates THB from people smuggling even though some smuggling situations can translate or degenerate into human trafficking (Kleemans, 2009).

Like enslavement, the word exploitation has legal and literal connotations both of which do not differ in substance (Allain, 2008); and in relation to THB there is no single definition. This is advantageous because a single definition could potentially limit the scope of punishable exploitation. But Chang (Chang, 1998) argued that lack of a single/standard definition of exploitation would make it difficult to determine the point where exploitation begins. Against this backdrop, researchers and prosecutors have long taken the easy way out by relying on the ILO Forced Labour Convention's definition of forced labour to explain what exploitation means. The Convention provides: "forced or compulsory labour shall mean all work or service that exacted from any person under the 
menace of any penalty and for which the said person has offered himself voluntarily" (article 2, Forced Labour Convention). Typically, while exploitation is an embodiment of other ingredients of THB such as coercion, fraud, violence and enslavement, forced labour constitutes a form of exploitation (Limoncelli, 2009; Todres, 2009). In furtherance of the ideals of the 1929 Convention, the 1930 Forced Labour Convention was adopted to eradicate incidents of forced labour among people. It basically addresses labour issues to the exclusion of all others. Therefore, to the extent that exploitation in THB is not limited to forced labour, the Convention cannot be said to effectively explain exploitation. This is so because exploitation in THB could be in relation to sex, pornography, organ harvesting, marriage and begging, amongst others. Therefore, it is easier to explain exploitation as a condition of enslavement. That way, it would be applicable in all cases of THB for forced or bonded labour-whether as domestics, labour in sweatshops, the plantations, or begging, sex work and pornography and not otherwise. All these are associated with enslavement, which makes it even more sensible to explain exploitation from the point of view of enslavement.

Generally, there are two types of exploitation, i.e. physical coercion involving forced work and injury from beating and torture; and psychological coercion. This shows that understanding the meaning of coercion is fundamental to the appreciation of the element of exploitation in THB.

The definition of coercion is quite expansive; and seems to reflect the concerted input and interest of human rights and feminist lobbyists in the drafting of TIPP. Coercion goes beyond physical force or even mental domination to include 'abuse of a position of vulnerability' which can potentially encompass a wide range of situations, since poverty, lack of education; displacement, illness as well as hunger can constitute a position of vulnerability. Largely, it is not everyone that is regarded as vulnerable unless the law providing for THB attaches vulnerability to everyone. Under the TIPPEAA, vulnerability is not gender sensitive as the Act applies to everybody and anybody. For example, s. 13 (3) provides:

... abuse of a position of vulnerability to include "intentionally using or otherwise taking advantage of an individual's personal, situational or circumstantial vulnerability to recruit, transport, transfer, harbour or receive that person for the purpose of exploiting him or her, such that the person believes submitting to the will of the abuser is the only real or acceptable option available to him or her and that this belief is reasonable in the light of the victims situation.

Under the TIPP, the extent to which a victim can be regarded as vulnerable is limited, as certain considerations have been stipulated. For example, the TIPP enjoins states to a) take into account "the age, gender and special needs of victims of trafficking" when providing protection and assistance to victims of THB (article 6, TIPP); b) recognize the special needs of children, including appropriate housing, education and care (article 24, TIPP) and c) recognize that trafficking could involve "abuse ... of a position of vulnerability" (article 3, TIPP).

Unlike the TIPPEAA, the TIPP did not define what constitutes "abuse of a 
position of vulnerability", but the travauxpréparatoires to TIPP states, "reference to the abuse of a position of vulnerability is understood to refer to any situation in which the person involved has no real and acceptable alternative but to submit to the abuse involved" (UN Doc A/55). The TIPPEAA definition of THB does not make reference to THB involving "abuse of position of vulnerability" but recognises child vulnerability, which accounts for its emphasis on trafficking of "persons below the age of eighteen" (ss. 16-19 of TIPPEAA. 2015).

With regards to psychological coercion, the defining ingredients, as highlighted by USDOS (USDOS, 2007) and Hughes (Hughes, 2000) are: force, fraud, pressure exerted on the victim to perform or remain in service to another, blackmail and threat of force. Notably, these are ingredients of exploitation, which are usually present in all forms of THB. According to Piotrowicz (Piotrowicz, 2002), the presence of subsequent exploitation needs to be present for an act to constitute trafficking. However, subsequent exploitationis usually not present in all cases of THB. A critical example is where there is an early interception by the law enforcement officials either in countries of origin, transit or destination, which can occur at any point in the trafficking chain. Note that even where exploitation is yet to take place, the action-transportation, recruitment, etc. with criminal intent suffices to hold perpetrators liable for trafficking.

Also, actions following victim's rescue, such as rehabilitation and protection services for victims, arrest and prosecution of suspected traffickers points to one fact-that THB has taken place. It does not matter that the victim had not at the time been exploited (Ahuja, 2009, Limoncelli, 2009). Therefore, the suspected trafficker can be charged either for the full offence of THB or attempted THB depending on the strength of evidence adduced in the particular case (ss. 29, 30 of TIPPEAA, 2015). For example, a person who has recruited or transported victims or attempted to do so with intent to traffic can be charged with the offence, as long as the process of recruiting or transporting victims with intent to traffic has began (Stolz, B., 2005).

Possibility of sustaining conviction for either the full offence arises from the following: a) exploitation may be present at every stage of the trafficking chain (Ahuja, 2009); and b) a suspected recruiter, may also benefit from exploitation of the victims even if he or she is not directly involved in the exploitation of THB victims (Fayomi, 2009). For example, the recruiter who coerces, fraudulently or forcefully recruits victim for the purpose of trafficking exploits the vulnerability of the victim; the transporter who moves the victim away from the security, safety and comfort of his or home and family through illegal means-sometimes through dangerous mode of transportation exploits the victim; and the exploiter who enslaves and force the victim into situation of sexual or non-sexual exploitation violates the human rights of victims. Exploitation itself is surely engendered by a number of socio-economic and political factors such as poverty, lack of accountability and transparency, corruption, illiteracy, certain socio-cultural practices, etc.

Recently high level of insecurity in Nigeria, characterised by insurgency, kid- 
nappings, armed banditry, political assassinations has contributed in making people more vulnerable to trafficking (Human Rights Watch, World Report, 2019). Generally, government in Nigeria is tackling socio-economic and political factors that make people vulnerable to exploitation. However, government's effort is grossly inadequate, calling for more effective anti-THB efforts in the country.

\section{Impacts of THB}

The ramifications of the impacts of THB are enormous for victims and the affected countries-source, transit and destination countries, particularly Nigeria. As already noted, victims of THB usually suffer both physical and psychological trauma arising from inhuman treatment to which they are often subjected, throughout the process of THB. It is incontrovertible that THB is characterised by victims being enslaved and exploited in circumstances that could be harmful to their mental and physical health. For example, in the particular context where victims are exploited in sex slavery, health of the victim is impacted as they are exposed to the risk of HIV/AIDS and other sexually transmitted diseases (Browne, E. 2015), and also of spreading these diseases to the wider public.

In Nigeria for example, there were incidences of reported deaths of THB victims arising from infectious diseases (Worsnop, 2019). Where victims have been rescued, reintegrating them into their families and society had been problematic due to rejection and stigmatization, leading to re-trafficking (UNICEF, 2018).

Generally in THB transactions, the human rights of victims are taken away and assumed by the trafficker(s). From the point of recruitment, through transportation to exploitation, the victims' rights to life, liberty, freedom of movement, dignity etc. enshrined in international human rights instruments and the CFRN are infringed. In the case of children, they are also striped of both the rights enshrined in the CFRN, and the special rights to development, education, etc. under several international and regional instruments as well as the Nigerian CRA.

THB does not only exert pressure on a country's resources, it undermines the rule of law and integrity of the country and constitutes threat to the country's national security (Browne, E., 2015). This is so because of the involvement of organised and loosely organised criminal groups, whose clandestine activities usually extend to other illicit activities beyond THB. When criminals operate, they act in violation of the laws of the country that have been carefully crafted and enacted to preserve the sanctity of nationhood; and sovereignty of states in the case of cross border trafficking. In combating THB, enormous resources-financial, material and human, which would have been channeled towards the provision of welfare services for the entire country, are often deployed to anti-THB fight. This is retrogressive, making it imperative for government and stakeholders to engage anti-THB measures proactively, vigorously and meaningfully. To be successful, these measures must be integrated and holistically. 


\section{Recommendations}

Having critically examined the three componential parts: transportation, enslavement and exploitation of THB as the constituent elements constituting crime in the THB and based on our critical analysis and the observation thereof, below are some of the recommendations:

\subsection{Transportation}

Having established through some Nigerian statutory provisions as well as the international provisions supported by some decided cases and the two legal maxim that transportation in no doubt plays a key role in the commission of THB. It is germane that more efforts should be intensified toward ensuring (enforcement of the various provisions of law and policies) those transportations companies take their responsibilities seriously to curtail being used by traffickers as medium for carrying out their nefarious activities of human trafficking in $\mathrm{Ni}$ geria.

Measures should targeted at creating more awareness about THB at stations and offices-airports, Bus stations, railway stations, harbour, motor parks etc. particularly, staff training on how to identity and respond to incidence of THB.

Government needs to provide national holistic anti-THB approaches to enable common people get involved in curbing the excesses of human trafficking in all ramifications by intersecting THB situation in Nigeria and globally.

\subsection{Enslavement}

Enslavement is another pertinent issue usually embedded in some socio-cultural practices in Nigeria, it is important to sensitise the populace, particularly the rural people on how such practices engender THB and the need to desist from them.

Identifying enslavement in THB is sometimes difficult for various reasons; hence, law enforcement operatives and others involved in anti-THB work should be vigorously trained on how to identify situations of enslavement.

\subsection{Exploitation}

Exploitation of persons who are victims of THB arises out of a number of factors that make people vulnerable. They include bad governance, poverty, and lack of opportunities among others. it is important to address all the factors, both social and economics, that make people vulnerable to trafficking.

For any meaningful impact to be felt in anti-THB effort in Nigeria, effective law enforcement must necessarily combine good policy formulation and adequate implementation of such policies. Weak law enforcement occasioned by frustrations-technicality and length of court proceedings.

\section{Conclusion}

THB is a process of enslaving people involving, among other elements, trans- 
porting people into situations of exploitation. This paper has attempted the examination of the three constituent elements that are critical to the execution of trafficking in human beings, whether within Nigeria or the trans-border or cross border transportation of victims. The three key elements: transportation, Enslavement and Exploitation have been examined with the intention of establishing relationship between the three elements and the THB.

Indeed, from the available data through cases and other literature reviewed, it was established the three elements constitute a full proof that these elements form integral parts to sustain the crime of THB. Especially when in several cases cited it was established that the transportation of victims in itself constitutes a physical element (actus reus) once the intention (mens-rea) to commit THB is evidence. As noted by Antislavery International, victims of THB do not necessarily have to be transported across border for the crime to take place (Antislavery International, 2019). It suffices if a person is moved from one point to another even within the same house, with intent to exploit. The conduct of enslaving anybody surely offends humanity and the law; and since everyone is entitled to enjoyment of rights as agreed by the international community under the Universal Declaration of Human Rights (United Nations, 1948), no one should really have to be subjected to inhuman treatment or be exploited for economic and other gains. This calls for strict legal interpretation, effective law enforcement. Beyond that, there is need to address key factors (such as, unemployment, high poverty level of citizens, low salaries for working, lack of effective enforcement of rules regulating THB) that make people vulnerable to exploitation.

\section{Conflicts of Interest}

The authors declare no conflicts of interest regarding the publication of this paper.

\section{References}

Abdulraheem, S., \& Oladipo, A. R. (2010). Trafficking in Women and Children: A Hidden Health and Social Problem in Nigeria. International Journal of Sociology and Anthropology, 2, 34-39.

Ahuja, J. (2009). Trafficking in Women and Children: Myths \& Realities (pp. 48-55). Delhi: Concept Publishing Company.

Allain, J. (2007). The Definition of "Slavery" in General International Law and the Crime of Enslavement within the Rome Statute (26 April, 2007) (pp. 1-22). Guest Lectures Series of the Office of the Prosecutor; ICC-CPI and Individual Authors.

Allain, J. (2008). Book Review: Trafficking in Human Beings: Modern Slavery. European Journal of International Law, 20, 453-457. https://doi.org/10.1093/ejil/chp013

Amuda, Y. (2011). Child Education in Nigeria: Hindrances and Solutions. Social and Behavioral Sciences, 15, 3027-3031. https://doi.org/10.1016/j.sbspro.2011.04.237

Antislavery International (1926). Slavery Convention. https://www.ohchr.org/EN/ProfessionalInterest/Pages/SlaveryConvention.aspx

Antislavery International (2019). Antislavery International, What Is Human Trafficking? http://www.antislavery.org 
Ashworth, A. (2006). Principles of Criminal Law (pp. 4-6). Oxford: Oxford University Press.

Bales, K., \& Soodalter, R. (2009). The Slave Next Door: Human Trafficking and Slavery in America Today (pp. 78-117). Berkeley, CA: University of California Press.

Browne, E. (2015). Drivers of Irregular Migration (pp. 3-4). Help Desk Research Report, Governance, Social Development, Humanitarian, Conflict.

Chang, J. (1998). Redirecting the Debate over Trafficking in Women: Definitions, Paradigms and Contexts. Harvard Human Rights Journal, 11, 63-65.

Cockell, J. (2000). Conceptualizing Peace Building: Human Security and Sustainable Peace. In M. Pugh (Ed.), Research of War-Torn Societies (p. 21). London: Macmillan Press. https://doi.org/10.1007/978-1-349-62835-3 2

Committee on the Rights of the Child (2019). Report of Nigeria. http://www.ohchr.org/EN/HRBodies/CRC/Pages/CRCIndex.aspx

Denton, E. (2010). International News Coverage of Human Trafficking Arrests and Prosecutions: A Content Analysis. Women and Criminal Justice, 20, 10-26. https://doi.org/10.1080/08974451003641321

Diamond, S. (1987). In Search of the Primitive: A Critique of Civilization (pp. 20-36, 225-244). New Brunswick: Transaction Publishers.

Duffy, H. (2009). Hadijatou Mani Koroua v Niger: Slavery Unveiled by ECOWAS Court. Human Rights Law Review, 9, 151-170. https://doi.org/10.1093/hrlr/ngn041

Edward, A. (2008). Trafficking in Human Beings: At the Intersection of Criminal Justice, Human Rights, Asylum/Immigration and Labour. Denver Journal of International Law and Policy, 36, 9-54.

Equality Now (2019). Sex Trafficking Campaign. https://www.equalitynow.org/sex trafficking campaign

Fayomi, O. (2009). Women, Poverty and Trafficking: A Contextual Exposition of the Nigerian Situation. Journal of Management and Social Sciences, 5, 65-79.

Fitzgibbon, L. K. (2003). Modern Day Slavery? The Scope of Trafficking in Persons in Africa. Africa Security Review, 12, 81-89. https://doi.org/10.1080/10246029.2003.9627573

Friesendorf, C. (2007). Pathologies of Security Governance: Efforts against Human Trafficking in Europe. Security Dialogue, 38, 379-402. https://doi.org/10.1177/0967010607081518

Gallagher, A., \& Holmes, P. (2008). Developing Effective Criminal Justice Response to Human Trafficking: Lessons from the Frontline. International Criminal Justice Review, 18, 318-343. https://doi.org/10.1177/1057567708320746

Geis, G., \& Brown, G. C. (2008). The Transnational Traffic in Human Body Parts. Journal of Contemporary Criminal Justice, 24, 212-224. https://doi.org/10.1177/1043986208318207

Gould, C. (2006). Countering Human Trafficking: Considerations and Constraints. South African Crime Quarterly, 16, 19-25. https://doi.org/10.17159/2413-3108/2006/v0i16a996

Harper Collins (2006). The Collins English Dictionary and Thesaurus Collins English Dictionary \& Thesaurus (pp. 390, 415). New York: HarperCollins Publishers.

Hughes, D. M. (2000). The "Natasha" Trade: The Transnational Shadow of Market of Trafficking Women. Journal of International Affairs, 53, 625-651.

ILO (2017). Global Estimates of Modern Day Slavery: Forced Labour and Forced Marriage (pp. 21-39). Geneva: ILO. 
International Office for Migration (2018). Irregular Migration. Essentials of Migration Management, 3, 3-10. http://www.iom.org

International Office for Migration (2018). World Migration Report. Geneva: IOM.

IOM (2019). Increased Number of Nigerian Women Fall Victim to Sex Trafficking, Exploitation in Mali. https://www.iom.int/news/increased-number-nigerian-migrants-fall-victim-sex-traffic king-exploitation-mali

Kempadoo, K. (2007). The War on Human Trafficking in the Caribbean. Race and Class, 49, 79-85. https://doi.org/10.1177/03063968070490020602

Kleemans, E. (2009). Human Smuggling and Human Trafficking. In M. Tonry (Ed.), The Oxford Handbook of Crime and Public Policy (pp. 409-414). Oxford: Oxford University Press.

Kleimenov, M., \& Shamkov, S. (2005). Criminal Transportation of Persons: Trends and Recommendations. In Y. Shelley, \& S. Stoecker (Eds.), Human Traffic and Transnational Crime: Eurasian and American Perspectives (pp. 29-46). Lanham, MD: Rowman \& Littlefield Publishers Inc.

Limoncelli, S. A. (2009). Human Trafficking, Globalization, Exploitation and Transnational Sociology. Sociology Compass, 3, 72-91.

https://doi.org/10.1111/j.1751-9020.2008.00178.x

Manning, P. (1983). Contours of Slavery and Social Change in Africa. The American Historical Review, 88, 835-857. https://doi.org/10.2307/1874022

Mills, W. H. (2001). Evolution of Society: From Savagery to Industrial Republic (pp. 6-7). Honolulu, HI: University Press of the Pacific.

Naim, M., \& Myers, J. (2005). Illicit: How Smugglers, Traffickers, and Copycats Are Hijacking the Global Economy (pp. 12-37). New York: Anchor Books, Random House Inc.

NAPTIP (2019). Over 2, 114 Nigerians Brought Back from Libya since January 2019. http://www.naptip.gov.ng

Nima Elbagir, N., Razek, R., Platt, A., \& Jones, B. (2017). People for Sale: Where Lives Are Auctioned for \$400. Exclusive Report, CNN, 15 November 2017.

Nwogu, V. (2007). Nigeria. In K. Skrivankova (Ed.), Collateral Damage: The Impact of Anti-Trafficking Measures on Human Rights across the World (pp. 142-170). Bangkok: Global Alliance against Traffic in Women.

https://www.iom.int/jahia/webdav/shared/shared/mainsite/microsites/IDM/workshops Lensuring protection 070909/collateral damage gaatw 2007.pdf

Obokata, T. (2003). Human Trafficking: Human Rights and the Nationality, Immigration and Asylum Act, 2002. European Human Rights Law Review, 4, 410-422.

Olujuwon, T. (2009). Combating Trafficking in Persons: A Case of Nigeria. European Journal of Social Sciences, 3, 20-28.

Organisation for Security and Co-operation in Europe OSCE (2015). Commentary to the OSCE Action Plan to Combat Trafficking in Human Beings; the 2005 Addendum Addressing Special Needs of Child Victim of Trafficking for Protection and Assistance; and 2013 Addendum to the OSCE Action Plan to Combat Trafficking in Human Beings: One Decade Later (pp. 34-44).

Orhant, M. (2001). Trafficking in Persons: Myths, Methods and Human Rights. Washington DC: Population Reference Bureau.

https://www.prb.org/traffickinginpersonsmythsmethodsandhumanrights/ 
Pennington, J. et al. (2009). The Cross-National Market in Human Beings. Journal of Macromarketing, 29, 119-134. https://doi.org/10.1177/0276146708327630

Piotrowicz, R. (2002). European Initiatives in the Protection of Victims of Trafficking Who Give Evidence against Their Traffickers. International Journal of Refugee Law, 14, 263, 266. https://doi.org/10.1093/ijrl/14.2 and 3.263

Scarpa, S. (2008). Trafficking in Human Beings: Modern Slavery (pp. 83-136). Oxford: Oxford University Press. https://doi.org/10.1093/acprof:oso/9780199541904.001.0001

Scheper-Hughes, N. (2000). The Global Traffic in Human Organs. Current Anthropology, 41, 191-224. https://doi.org/10.1086/300123

Stoddard, A. (2009). Senate 1: Human Trafficking. In Harvard Model Congress (Vol. 155, Pt. 7, 8515, 8533).

https://www.govinfo.gov/content/pkg/CRECB-2009-pt7/pdf/CRECB-2009-pt7-issue-2 009-03-25.pdf

Stolz, B. (2005). Educating Policymakers and Setting the Criminal Justice Policymaking Agenda: Interest Groups and the Victims of Trafficking and Violence Act of 2000. Criminal Justice, 5, 407-430. https://doi.org/10.1177/1466802505057718

Todres, J. (2009). Law, Otherness and Human Trafficking. Santa Clara Law Review, 49, 605-672.

Truong, T. (2008). Human Trafficking and New Patterns of Migration, Gender. Technology and Development, 12, 5-8. https://doi.org/10.1177/097185240701200102

Turner, J., \& Kelly, L. (2009). Trade Secrets: Intersection between Diasporas and Crime Groups in the Constitution of Human Trafficking Chain. British Journal of Criminology, 49, 184-201. https://doi.org/10.1093/bjc/azn079

UN.GIFT (2008). United Nations Global Initiative to Fight Human Trafficking: An Overview (p.1). http://www.ungift.org/docs/ungift/pdf/knowledge/ebook.pdf

UNESCO (2006). Human Trafficking in Nigeria; Root Causes and Recommendations (pp. 31-36).UNESCO, Policy Paper Poverty Series No. 14 (E).

UNICEF (2018). End Stigmatization, End Trafficking. http://www.unicefusa.org

United Nations (2019). Visit to Nigeria: Report of the UN Special Rapporteur on Trafficking in Persons (A/HRC/41/46/Add.1), 16 April 2019.

UNODC (2013). Drug Trafficking Patterns to and from Eastern Africa. http://www.unodc.org

UNODC (2018). Global Report on Trafficking in Persons (pp. 81-83). http://www.unodc.org

UNODC (2019). Human Trafficking. http://www.unodc.org

USDOS (2007). Trafficking in Persons Report. https://2001-2009.state.gov/g/tip/rls/tiprpt/2007

USDOS (2010). Trafficking in Persons Report. https://2009-2017.state.gov/j/tip/rls/tiprpt/2010

USDOS (2019). Trafficking in Persons Report (p. 335). http://www.state.gov/g/tip/rls/tiprpt/2019

Usher, D. H. (1979). From African Captivity to American Slavery: The Introduction of Black Labourers to Colonial Louisiana. The Journal of the Louisiana Historical Association, 20, 25-48.

Worsnop, C. Z. (2019). The Disease Outbreak-Human Trafficking Connection: A Missed Opportunity. Health Security, 17, 181-192. https://doi.org/10.1089/hs.2018.0134 


\section{Statutes}

Nigeria, (1999). Constitution of the Federal Republic of Nigeria.

Penal Code OF Nigeria.

Criminal Code of Nigeria.

Nigeria, (2015). Violence Against Persons (Prohibition) Act.

Nigeria, (2015). Trafficking in Persons (Prohibition) Enforcement and Administration Act (TIPPEAA), 2015. Nigeria (2003)\#

\section{Cases}

Babalola \& Ors v State (1989) LPELR-695 (SC)

Bassey v Attorney General of the Federation (2015) LPELR40425 (CA),

Idagu v State (2018) LPELR-44343.

Omadiareb \& Anor v AGF (2013) LPELR-20061 (CA)

R v Warburton [2006] ECWA (Crim 627),

Speiss v oni (2016) LPELR-40502 (SC))

Ukpong v State (2019) LPELR-46427 (SC) 